\title{
Issues in Courtroom Security: a key role for the private sector in Australia and New Zealand
}

\section{Rick Sarre}

School of Commerce and School of Law, University of South Australia, Adelaide, 5000, Australia. E-mail: rick.sarre@unisa.edu.au

\section{Tim Prenzler}

Australian Research Council Centre of Excellence in Policing and Security, Griffith University, Brisbane, Queensland 4111, Australia. E-mail: t.prenzler@griffith.edu.au

Published in Security Journal, 2012, 25(1), 25-37.

There are two important trends emerging in the science of court security worldwide. The first is the trend towards security and risk management, and the heightened responsibility that now rests with the courts to protect those who work or visit there. This trend comes in response to a number of incidents in which people have been killed or injured at the hands of offenders in and around law court buildings. The second is the trend to courts administrators contracting with private security personnel. Over the last quarter century, and around the world, there has been a widespread shifting of security functions from public to private hands. Today, private sector employees are well recognized as important players in prisoner transport and court security generally. Such contracting 'in' of security services has much to offer those responsible for risk management of courts. Using a case study approach, and drawing upon examples of law courts from jurisdictions across Australia and New Zealand, the authors conclude that it is possible to secure courtrooms to a far greater degree than has been the case in the past without jeopardizing the important feature of curial 'openness'.

Key words: court security; private sector policing; courtroom risks.

\section{Introduction}

In the last twenty years, courts administrators around Australia and New Zealand have become increasingly aware of the importance of security. These initiatives have followed trends that have been established in the United States (Raftery, 2007; Barrett, 2009; Etter and Swymeler, 2010). Cooper, reflecting upon three decades of US developments, writes:

No longer is 'court security' a function to be delegated primarily to the sheriff's department or other law enforcement agency, but it is rather a critical responsibility of judges and court administrative staff, who must work in partnership with law-enforcement and other professionals to ensure the safety, security, and integrity of the judicial process and the full range of personnel, facilities, systems, and other components upon which it relies. The implications of this shift in definition for judicial administration are also significant. Court security is now an integral part of the responsibilities of court administration, reflecting the increasing recognition that the issue of 'court security' and the responsibility for ensuring 'continuity of court operations' are inextricably intertwined. (Cooper, 2007, p 45)

Today, in and around Australia and New Zealand courts, security systems and other security tools such as duress alarms, CCTV monitoring, hand held scanners and metal detectors are now commonplace. Courts administrators have taken extraordinary steps to ensure that those entering their courts pass through a secure point of entry. To do this effectively, they have engaged the assistance of design experts (see Figure 1). While the employment of staff to undertake security measures used to be referred to, colloquially, as contracting 'out' of such services, the more favoured term is now contracting 'in'. The 
importance of this distinction cannot be overstated. When some function is contracted out, there is usually a corresponding outsourcing of legal responsibility. When a function is contracted in, the legal responsibility rests firmly with the principal, in this case the various courts authorities. Indeed, we can now safely assume that court security is a vital part of court administrators' duties and responsibilities.

\section{Violent incidents in courts and their environs in Australia and New Zealand}

These developments in security awareness, risk assessment and preparedness have arisen in response to the perception that there has been an increase in dangerous incidents in courtrooms and their environs (Sarre and Prenzler, 2011). For example, it was stated by the New South Wales (NSW) Attorney-General in October 2009 that there are, on average, 300 'security incidents' monthly in NSW courts (Attorney-General, 2009). While that statement does not include a definition of 'incident', it is, nonetheless, a significant figure.

Whether or not there has been an actual (rather than perceived) increase in security incidents is also not known. There is no base-line dataset in Australia or New Zealand that can allow that assumption to be made safely. It is incontrovertible, however, that there have been, in the last two decades, many tragic courtroom incidents, especially on the eastern side of the Tasman Sea. For example, in 1990, a 16 year old lad took a machete into a New Zealand Children's Court and hit Judge Dame Augusta Wallace in the face (Dominion Post, 2008). In 1998, a man stabbed to death his former partner in a waiting room at the Palmerston North Family Court (Dominion Post, 2008). Elsewhere in New Zealand, in 2005, lawyer Greg King was hit with a chair when a man rushed from the public gallery of the Porirua District Court to attack a murder accused (Southland Times, 2008). In 2006, an accused leapt out of his seat in the secure prisoner area (the 'dock') to punch Judge Geoff Ellis in the Nelson District Court (Southland Times, 2008). In 2007, a man stabbed another in the neck in the foyer of the Wellington District Court (Southland Times, 2008) and, finally, in February 2010, an offender sliced her arm with a razor blade in the New Plymouth District Court in an act of self harm (Taranaki Daily News, 2010).

There have been similar tales on the other side of the Tasman. In 1999, there was a dramatic siege in the South Australian Supreme Court after a former police officer, who had just been sentenced for armed robbery, pulled out a knife, jumped over the barrier separating him from the bar table and judge's bench, and held the knife to the throat of a court stenographer, holding her hostage and threatening to kill her (ABC, 1999).

In June 2004, in Perth, Western Australia, nine prisoners escaped from court custody by overpowering three private security guards in the Supreme Court, stealing a key which allowed them to exit the building. Thereafter, the felons hijacked two vehicles from people who happened to be driving past the court (Pennells, 2004). The escape caused public alarm and triggered a massive manhunt by police across Perth's southern suburbs, including a high speed vehicle pursuit and the shutdown of a freeway (Prenzler and Sarre, 2008a). Other examples from Australian courts include a social worker being threatened with a knife in the Victorian Children's Court (Sunday Herald Sun, August 2008), a woman armed with a knife and a pair of scissors threatening to kill herself during court proceedings (AAP, May 2008), and a female prosecutor being attacked by a mentally ill offender in the Australian Capital Territory Supreme Court (Canberra Times, 2010).

It is not only in the court environs that dangers lurk. On 23 June 1980, an Australian Family Court judge, Justice David Opas, died from abdominal wounds after being shot by an unknown assailant at his Sydney home. Police investigators believe the assassin, who was never caught, was an aggrieved party seeking revenge over an adverse judgement arising out of a bitter domestic legal wrangle.

There are dangers for security staff as well. Indeed, occupational health and safety data show security officers in the top three jobs for work-related homicides, with police and taxi drivers coming in at number one and two respectively (Prenzler and Sarre, 2010).

The consequence of all of this has been a massive injection of public funding into court security, along 
with training and infrastructure and research into what has become known in many institutions of higher learning as 'security studies'. The trend is undeniable, and linked strongly to the political inertia for infrastructure 'hardening' that often emerges in the aftermath of any security breakdown. It is noteworthy that policy-makers have rarely applied their minds to the security arrangements that could and should be in place for non-court public spaces where, arguably, emotions run just as high, such as neighbourhood justice centres and family relationship centres.

\section{Prisoner transportation}

There is a significant role played in some jurisdictions by the private sector in providing prisoner transport services, too. Prisoner transport contracts are, by and large, between the security company and the legal entity representing correctional services and with police. They are not contracts with court services (Boswell, 2003).

Sadly, there have been some significant security and safety failures in these services in recent memory.

In October 2006, an inter-prison van operated by the Australian Integration Management Services (AIMS) corporation broke down in Western Australia on a day when the temperature reached 40.5 Celsius. The van was about three hours into a nine hour journey to Roebourne Prison. Notwithstanding the heat of the day, the fourteen prisoners were kept in the van without air conditioning or forced ventilation. Not surprisingly, the men all reported extreme discomfort. The journey eventually took over 20 hours, after recovery vehicles were finally despatched from Roebourne, six hours away (Office of the Inspector of Custodial Services, 2007b).

In January of 2008, a Mr Ward, an Indigenous man who had been charged with drink driving, died from heatstroke in the back of a private security custodial transport vehicle operated by Global Solutions Limited (GSL) during a four hour drive from the courthouse in Laverton, Western Australia, to prison in Kalgoorlie. The case highlights the dangers associated with the privatisation of services that involve a non-delegable duty of care.

The Ward case represented a contract management failure, that is, a failure of the Department's contract management systems to ensure that custodial transport services were operated in a way consistent with the duty of care owed to Mr Ward, as required under the Court Security and Custodial Services Act 1999 (Office of the Inspector of Custodial Services, 2010, p 55).

The 2010 report of the Office of the Inspector of Custodial Services includes a diagram showing a court security and custodial services contract governance 'flow' chart for the period February 2006 to October 2008. It shows the vast array of government bodies involved in awarding and monitoring contracts, including three Ministers, two Commissioners, three department heads and the CEO of the Department of the Attorney-General (Office of the Inspector of Custodial Services, 2010, p 59). The implications for accountability in the delivery of court security services and correctional transport services are obvious.

The death of $\mathrm{Mr}$ Ward gave rise to a formal review of prisoner transport services by the Department for Correctional Services. The review was tabled in the Western Australian parliament on 26 February 2008 (Government of Western Australia, 2008). According to the Inspector of Custodial Services, the review marked a turning point in contract management. 'Stringent procedures' were necessary, said the report, to guarantee the safety of persons in the custody of the department, who should now be 'squarely at the centre of its focus in its relations with the Contractor' (Office of the Inspector of Custodial Services, $2010, \mathrm{p} 65)$. The Inspector concluded that ' $[\mathrm{m}]$ ost of the reforms outlined in the review were pursued energetically by the new contract management team more or less in accord with the deadlines that had been set' (Office of the Inspector of Custodial Services, 2010, p 65).

The case involving the escape of the nine prisoners from the Western Australian Supreme Court in June 2004 (referred to above) was also the subject of a report of the Inspector of Custodial Services. The report provides a salient reminder of the importance of ensuring a professional, high quality service in prisoner 
transport:

The usual mode of assessing whether privatisation of criminal justice services has been successful is to look at the performance of the contractor in providing those services - in this case [the] AIMS [Corporation]. That is obviously the core question. However, the attitude and skills of the purchaser - the Department of Justice and ultimately the State of Western Australia - are also relevant. If the performance of the contractor is not up to standard, the likelihood is that the performance of the purchaser in managing the contract is also not up to standard. The State cannot obliterate its responsibility and risk by contracting out services, so the purchaser must remain vigilant and involved (Office of the Inspector of Custodial Services, 2006, p iii).

\section{Risk management in courts}

The list of incidents recited earlier highlights the potential danger to judicial officers, court staff, litigants, legal aid officers, court volunteers, the public and those on trial in the event of lax security. There is an undeniable moral duty resting on the state to ensure that state functions are carried out in such a manner as to prevent or forestall harm to anyone. But there is also a legal risk associated with poor security. There are potential civil liabilities attaching to any government that does not secure accused persons or convicted offenders adequately while these people are in courtrooms, hospitals or during prisoner transportation. The law in these circumstances is clear. Any action (or inaction) by the state's officers (in this case, court staff or transport officers) that creates a dangerous environment for staff, litigants, the public or offenders themselves is potentially a breach of a duty of care.

The following cases reveal the legal duties owed to staff and to visitors generally. They do not derive from courtroom settings, however. They arise out of bank holdups and, in one case, an assault in a casino. But the legal principles are identical at law, and would potentially apply in any situation where a person was injured in or around a courtroom, including people who are in the courts not of their own volition.

On 3 June 1998, a gun was held to a bank teller's head during an armed hold-up. It occurred while a security company was delivering large quantities of cash to the bank. The teller suffered severe ongoing psychological trauma, but the New South Wales District Court initially denied her claim. Her appeal in the NSW Court of Appeal succeeded. Because the bank took receipt of large amounts of money in cash, and placed it in the unprotected custody of the teller, the court concluded they had made her an attractive target for an armed robber. Insufficient protection had been provided. There were no 'anti-jump' barriers, for example. The court said that the scope of a bank's duty clearly extends to protecting employees against robbery and any subsequent harm they might suffer. The risk, said the judge, was foreseeable. The bank had not taken reasonable care for the health and safety of its employees and their breach gave rise to the psychological injury that had been diagnosed. The court awarded the plaintiff US\$100,000 in damages. (Faucett v St George Bank [2003] NSWCA 43). It was not appealed.

Another case involved a patron of Crown Casino in downtown Melbourne. A Mr Hudson was attacked while at the casino. He sued the casino operators alleging negligence, arguing that their security had been lax. About 71 seconds had transpired between him being set upon by his assailant and security officers arriving on the scene. The question was whether the cause of the injury was the poor response time, and whether this delay was, in fact, negligent. The casino argued that, while it was under a common law duty of care to take reasonable care to protect people in Mr Hudson's position from illegal conduct, it had not failed in its duty. Mr Hudson nevertheless succeeded. He was awarded US $\$ 48,000$. The casino operators appealed. The appeal court dismissed the appeal, allowing Mr Hudson to keep his compensatory payout. (Crown Ltd v Hudson [2002] VSCA 28, Court of Appeal, Supreme Court of Victoria, No 6071 of 2000, March 2002) It is clear from this case, by extension, that the state would be vicariously liable to an injured person should a security officer in the precincts of a court act in a manner unbefitting of his or her office, and an injury occurred. 
Poor security practices often give rise to breaches of occupational health and safety laws, and may result in a financial penalty. Two recent cases illustrate this legal concept.

On 17 June 2002, three men jumped the counter of the Brookvale (New South Wales) branch of the Australia and New Zealand (ANZ) bank. Two of the three offenders managed to enter the cash handling area on the employee side of the banking counters by scaling a two-metre-high 'anti-jump barrier'. There was a 14 inch $(400 \mathrm{~mm})$ gap between the top of the barrier and the ceiling, allowing the offenders to gain access. Because this omission by the bank made its employees more vulnerable to robbery, the bank was found guilty of contravening section 8(1) of the Occupational Health and Safety Act 2000 (New South Wales). Judge Boland in the NSW Industrial Relations Commission (Derrick v ANZ Banking Group [2003] NSWIR Comm 406, 21 November 2003) noted that the bank had been previously criticized for inadequate security. The bank was fined US $\$ 150,000$ for not maintaining a safe workplace and failing to carry out adequate risk assessments.

A robbery occurred at Macquarie University, Sydney, on 15 March 2001. Chubb Securities later pleaded guilty to contravening section 16(1) of the Occupational Health and Safety Act 2000 (NSW) by not providing adequate training to its staff, and hence making them more vulnerable to robbery. The NSW Industrial Relations Commission fined the company US\$95,000 for failing to ensure the safety of the two security guards and a cashier who were the direct human victims of the robbery (Robinson $v$ Chubb Securities Australia Pty Ltd [2003] NSWIR Comm 467, 15 December 2003).

The courts thus appear to be sympathetic to the claims of victims of assaults where a duty of care is owed and breached, and where losses are foreseeable. Judges tend to award liability against those who should have better sought to secure the safety of staff and the public who become victims if there is evidence that too little was done to provide security in the face of foreseeable harm. These same principles would apply in courtrooms and in courthouse environs.

\section{The impact of private security options}

Over the last quarter century there has been a widespread shifting of security functions from public to private hands. Turning to the private sector for risk management and security in the courts, and for prisoner transport, is becoming a popular option for governments in general and sheriffs in particular, and, on the anecdotal evidence available, not unsuccessfully. This is part of a wider and broader trend towards privatisation of security functions generally (Sarre, 2005). The commercial demand for private contract security grows steadily upwards, and there is no part of the globe that has not been affected. Paid security providers, in terms of numbers of personnel and annual expenditures at the very least, now dominate the order maintenance landscape of a majority of countries in the world (van Steden and Sarre, 2007).

By way of illustration, the growth of the security industry is now considered one of the key features of the evolution of the 'policing complex' since the end of World War II. In a recent global review of crime and security, one Dutch commentator estimated that, in very approximate terms, '[w]orldwide, more people are employed as a private security officer $(348$ per 100,000) than as a police officer $(318$ per 100,000).' (van Dijk, 2008, p 15)

The most recent financial data for the Australian security industry (for 2005-06) show that the private security sector paid salaries and wages of US $\$ 1.4$ billion and had a gross income of US $\$ 4.2$ billion, which was 0.2 percent of all industry income reported by the Australian Bureau of Statistics. At the end of the financial year 2006/07 there were 5,523 registered 'security' businesses. 45 percent were sole operator companies. At the same time, about 45 percent of the market was dominated by five large firms. Approximately 92,500 'security' licenses issued by Australian security regulatory agencies were held by individuals across Australia in 2007 (Sarre and Prenzler, 2009).

All of this is not particularly surprising, given that the publicly funded agencies of order maintenance that evolved and grew during the nineteenth century development of modern policing never really eradicated the private forms of policing that had preceded them. The upshot of this resurgence is a modern mix of 
options. As Philip Stenning writes:

it is now almost impossible to identify any function or responsibility of the public police which is not, somewhere and under some circumstances, assumed and performed by private police in democratic societies. (Stenning, 2000, p. 328)

This trend has been seen as a consequence of continuing pressure by governments to involve citizens in their own policing, with private security personnel part of an 'extended police family' (Johnston, 2003). The terminology most often used to describe this hybrid landscape of order maintenance officers is 'plural policing' (Stenning, 2009). The debate over legal authority in that equation is an important one (Shichor and Gilbert, 2001; Sarre and Prenzler, 2009; Sarre, 2010) but it falls outside the parameters of this paper.

\section{Public/private partnerships in Australia and New Zealand: evidence from jurisdictions}

In this section we review the arrangements currently in place in Australian and New Zealand courts for a 'pluralised' approach. Some have embraced private options in total. One has not, rejecting the private option outright. Others have hybrid models.

\section{Method}

The authors conducted a search (via the press search engine Factiva) of court security incidents in the past decade in Australia and New Zealand as reported in the press (print and electronic). They also reviewed, through the Austlii website, court precedents (dated from 1998) dealing with court incidents where a legal judgment was made at the end of litigation. Finally, they contacted an officer in the courts departments of each of the jurisdictions in order to ascertain what legislation was relevant, and how it informed and affected their procedures related to court security. The results of those enquiries are found below in Table 1 .

\section{Western Australia}

In 2000, the Western Australian Ministry of Justice (now Department of Justice) was the first government department in Australia to introduce, by a 'license' system, the contracting 'in' of court security services and custodial services, prisoner transport and police 'lock-up' management, with police and private providers sharing jurisdiction in these areas (Harding, 2000). This was done pursuant to the power vested in the Ministry by the Court Security and Custodial Services Act 1999 (Western Australia). Under a contract signed on January 17, 2000, the provision of security services by a private company, in this case, the former AIMS Corporation, commenced on July 31, 2000. The powers of authorized contractors in relation to court security services are set out in the schedules to the Regulations, including power in relation to dealing with persons at court premises, power to search persons in custody, power to prevent communication with persons in custody and to refuse entry to, or remove visitors from, lock-ups and court custody centres. In August 2007, AIMS Corporation was taken over by the multinational company, G4S (formerly known as Group 4 Securicor). In May 2008, G4S also completed its acquisition of GSL.

\section{South Australia}

South Australia was the first Australian jurisdiction to introduce legislation relating to the security of courts. This was done via the Law Courts (Maintenance of Order) Act 1928 (SA). This Act was replaced in 2000 by amendments to the Sheriff's Act 1978 (SA). Indeed, South Australian court administrators embraced the private option in relation to prisoner transport four years earlier than their Western Australian counterparts, in December 1996. The contract for Prisoner Movement and In-Court Management in all courts (except the Supreme Court and District Court in Adelaide) was awarded to the private international contractor Group 4. All contracted staff are appointed as 'sheriff's officers' for the purposes of the contract. Thus, private security personnel provide an interface for their security transportation duties with courts on a day to day basis. Indeed, in the South Australian Magistrates Courts, the transportation security officers will sit with the prisoner in the dock. Under a new Part 3 of the 
Sheriff's Act 1978 (SA), the Sheriff can appoint sheriff's officers as security officers, and in South Australian courts these are trained 'in house' and employed 'in house.' Sheriff's officers thus conduct 'point of entry' searches. They are also rotated through the duties of court orderly, court security and prisoner security. They sit in the prisoner 'docks' of the Supreme Court and District Court. The G4S transportation security officers come no further than the door of the courtroom, where a hand-over occurs.

\section{Victoria}

The Court Security Act 1980 (Vic) established a scheme of 'authorized officers' for their court security. These include police officers or people appointed as authorized officers by the chief executive officer of a court. The Act also allows for security services to be contracted out. The Victorian Supreme Court, County Court and Magistrates Courts have all embraced the private sector, with contracts in existence with G4S, Independent Security Services (ISS), Wilsons, Liberty Group and Chubb. Indeed, there is now a 'pre-qualified' panel of these five security service companies from which agencies may draw and with whom they may contract, thus avoiding repeating the public tender process every time a new contract needs to be drawn.

\section{Australian Capital Territory}

In the ACT, the private firm Metropolitan Security Services (MSS) provides court security for both Supreme Court and Magistrates Courts.

\section{Northern Territory}

By virtue of the powers under the Court Security Act 1998 (NT), the courts have contracted 'in' a range of private providers. In the Supreme Court, MSS is used for prisoner transport, ISS is used for access and premises security, while Protective Security Officers (PSOs) are used for in-court security. The Northern Territory has also conferred all powers on police officers by making them (like all Sheriff's officers) 'security officers' under the Act (section 5(1)).

\section{New South Wales}

In New South Wales, private security providers have been completely scorned by the state's courts administrators. They are not used at all (unless the courts are managed by the Commonwealth, such as the Family Court or Federal Court.) Anecdotal evidence is that the courts administrators believe that the status quo does not need to be disturbed in the absence of a crisis.

\section{Queensland}

All court security is undertaken by government employed Protective Security Officers (PSOs) empowered under the State Buildings Protective Security Act 1983 (Qld). The role of PSOs in the broad spectrum of policing in Australia, not just in Queensland but in other States and in the Australian federal jurisdiction, is a significant phenomenon (Sarre, 2010). Queensland also grants police officers the majority of the powers of a court security officer (section 25).

\section{Tasmania}

The Admission to Courts Act 1916 (Tas) was designed to limit the common law principle of open courts by allowing admission to be regulated in the interests of public order, safety, public morals and decency. The Act allows for the appointment of authorized officers and allows regulations to be made in relation to admission to courts, conduct and control of people in a court and other matters relating to public order or safety. In Tasmania's Supreme Court, security is undertaken by government employed officers, although in the Magistrates Courts, private providers have now been contracted 'in'.

\section{Federal Courts}

The security of Commonwealth courts is guided by the Public Order (Protection of Persons and 
Property) Act 1971 (Cth). In all Federal Courts in Australia (the High Court, Family Court, Federal Court, Federal Magistrates Court) security is now managed by Wilson Security, a private operator.

\section{New Zealand}

The New Zealand Court Security Act 1999 (NZ) allows the chief executive to employ or contract for court security officers, and that has been happening for many years. There is a provision in the Act granting police officers, too, all the powers and duties given to court security officers (section 34). The potential for demarcation disputes between police officers and court security officers has been averted by the law-makers making it clear that court security officers are not to exercise powers against a person when a police officer is dealing with that person unless the police officers requests assistance (section 29). In New Zealand prisoner transport contracts usually include in-court management.

In Table 1, each of the relevant public/private partnerships (if applicable) is listed.

Table 1. Court Security Services Matrix

\begin{tabular}{|c|c|c|c|}
\hline Jurisdiction & Courts/Contacts & $\begin{array}{l}\text { Private } \\
\text { Security? } \\
\text { Y/N }\end{array}$ & Provider \\
\hline Federal & Commonwealth Courts & $\mathrm{Y}$ & Wilson Security \\
\hline ACT & $\begin{array}{l}\text { Supreme Court and Magistrates } \\
\text { Court }\end{array}$ & Y & $\begin{array}{l}\text { Metropolitan Security Services } \\
\text { (MSS) }\end{array}$ \\
\hline NSW & All courts & $\mathrm{N}$ & Sheriff's Officers \\
\hline \multirow[t]{2}{*}{$\begin{array}{l}\text { Northern } \\
\text { Territory }\end{array}$} & Supreme Court & $\mathrm{Y}$ & $\begin{array}{l}\text { MSS (custodial); Independent } \\
\text { Security Services (ISS) } \\
\text { (access, premises, etc.); PSOs } \\
\text { used for in-court security }\end{array}$ \\
\hline & Magistrates Court & $\mathrm{N}$ & Sheriff's Officers \\
\hline Queensland & All courts & $\mathrm{N}$ & $\begin{array}{l}\text { Government Protective } \\
\text { Security Officers (PSOs) }\end{array}$ \\
\hline \multirow[t]{2}{*}{ South Australia } & Supreme Court and District Court & $\mathrm{N}$ & Sheriff's Officers \\
\hline & Magistrates Court & $\mathrm{Y}$ & $\begin{array}{l}\text { G4S used for transportation \& } \\
\text { court security }\end{array}$ \\
\hline \multirow[t]{2}{*}{ Tasmania } & Supreme Court & $\mathrm{N}$ & Government \\
\hline & Magistrates Courts & $\mathrm{Y}$ & Dyson Security \\
\hline \multirow[t]{2}{*}{ Victoria } & Supreme Court & $\mathrm{Y}$ & $\begin{array}{l}\text { ISS; Wilson Security; Chubb; } \\
\text { G4S }\end{array}$ \\
\hline & County Court & $\mathrm{Y}$ & G4S + Liberty Group \\
\hline
\end{tabular}




\begin{tabular}{|l|l|l|l|}
\hline & Magistrates Court & Y & G4S \\
\hline $\begin{array}{l}\text { Western } \\
\text { Australia }\end{array}$ & All courts & Y & G4S \\
\hline New Zealand & All courts & N & Court Security Officers \\
\hline
\end{tabular}

\section{Discussion}

The handing over to the private sector of responsibility for court security, which has become such an important part of governmental services, does come at some risk. Is it possible to ensure that those who are employed (contracted 'in') to undertake such tasks do so with the care, attention and responsibility that befits the role? The conclusion of the Inspector of Custodial Services who reviewed this issue in the context of the Western Australian contracts in 2007 was sanguine.

It is now justifiable to say that the court custodial services aspect of the contract is working reasonably well. The judiciary by and large accept the privatised service model; persons in custody though not universally laudatory are on the whole appreciative of the considerate way in which they are treated; AIMS personnel have good working relationships with both Corrective Services and Police; and the costs to the State for the provision of these services is almost certainly markedly lower than if they were being provided in the previous ways. This is true both in the Metropolitan area and also, as this Report shows, in those regional areas covered by the contract. However, the organisational stresses are greater in the regions and the service provision accordingly somewhat more fragile. This is partly a consequence of labour market pressures, but it is also related to working conditions.... The paradox that arises out of the contracting out arrangements is that AIMS, as the employer, is not authorised to address this issue as the property from which they provide their services is owned by someone else - the Department of the Attorney General. (Office of the Inspector of Custodial Services 2007a, p iii)

To address the accountability issues, each State and Territory in Australia has developed a licensing system for security providers that resulted from a major shift, mainly in the 1990s, from partial and minimalist forms of occupational registration to full license requirements (Prenzler, 2000). This 'first wave' of reform coincided with an upsurge in security personnel, and entailed compulsory pre-entry training and a set of disqualifying criminal offences for licenses. The main occupational groups targeted by these changes were private contract security firms, guards, crowd controllers and private investigators.

The general direction of the new licensing systems has received widespread support from industry members, especially given the levels of malfeasance and misfeasance that occur from time to time in the security industry (Prenzler and Sarre, 2008a). But there is no national consistency with licensing. There is little more than a patchwork of standards and terminology across the eight Australian jurisdictions and no attempt to accord with New Zealand trends. In addition, while South Australia, Western Australia and later New South Wales developed comprehensive, or near-comprehensive, licensing regimes, other jurisdictions left out important areas of security work, such as in-house guarding, station monitoring and lock-smithing. There are continuing concerns about the extent to which criminal history checks are properly 'national.' Concerns persist about pre-entry training standards. These are highly variable, and limited to five days on average in most jurisdictions. There is little in the way of proactive auditing of an individual license-holder's conduct once licenses are issued.

On the other hand, jurisdictions have expanded training requirements consistent with international models of best practice (Button and George, 2006; Prenzler and Sarre, 1999; 2008b). Generally speaking, in the field of training, there has been a commitment by governments to performance measurement and evaluation with a view to continuous improvement of the security industry, although some 'sticking points remain, among them the award wages issues relating to management services as opposed to 
security services and prisoner transport.

Some final, albeit brief, mention should be made regarding the uncertainty over the powers wielded by private security officers vis-à-vis Sheriff's Officers. The powers and immunities of private security personnel are, generally speaking, unclear and inconsistent, dependent upon fine distinctions and differ markedly from those of the publicly appointed security staff, even though they are often carrying out many of the same tasks. This should be a concern for legal policy-making consideration (Sarre, 2010).

\section{Conclusion}

In the last few decades there has been a heightened awareness of the risks in and around court buildings, and security has been stepped up accordingly. The risks are not only to litigants and court staff in terms of injuries and death, but also to the taxpayer in terms of potential legal liabilities for damages in the event that a foreseeable injury occurs because of lax security. In order to manage these risks within budgets that can be accommodated, courts management and prisoner transport services have been turning to the private sector. Apart from the more obvious failures highlighted above, the experiment that began a decade ago appears to have worked well, but vigilance is required to ensure that appropriate entry standards, training requirements and licensing regimes remain at levels that match the risks at stake. Generally speaking, the 'report card' presents a positive picture:

The summary point is that the custodial services contract arrangements now seem well enough established to justify State instrumentalities in thinking about ways in which its benefits can be extended. The question posed at the outset of the contracting arrangements- "Can this arrangement work?" - has now been effectively displaced by the question, "Where do we go next?" ... [And] ..."When will the State put additional resources into these activities?" (Office of the Inspector of Custodial Services, 2007a, p iv).

There are competing interests here. The security arrangements that are put in place should not threaten nor jeopardize the openness of the courts, which has been a hallmark of our legal tradition for centuries, but nor should people who use the courts, or who are subject to, or responsible for, prisoner transport systems, be exposed to unreasonable risks. Finding the most appropriate balance is the crucial issue facing legislators, administrators and policy-makers alike. For the most part, private operators have been equal to the tasks expected of them in this regard, and should continue to play a key role well into the future.

\section{References}

AAP (2008) Federal Court Security Breached in NSW. AAP Bulletins. 29 May 2008.

ABC (1999) Woman taken hostage in courtroom siege World Today. 9 September. http://www.abc.net.au/worldtoday/stories/s50568.htm accessed 27 October 2010.

Attorney-General (2009) Press Release, October 18, Security procedures boosted to protect judges. New South Wales, Department of Justice and Attorney-General.

Barrett, J. (2009) Protecting Court: A Practitioner's Guide to Court Security, Minneapolis: Mill City Press.

Boswell, M. (2003) Management of the deprivation of liberty infrastructure: issues in public/private contracting for prisoner escorts, Paper presented to the Division of Business, University of SA, City West Campus, 30 October 2003.

Button, M. and George, B. (2006) Regulation of private security: models for analysis. In: M. Gill (ed.), The Handbook of Security. Houndmills, Hampshire: Palgrave Macmillan, pp. 563-585.

Canberra Times (2010) WorkCover presses panic button over court security, 31 March.

Cooper, C. (2007) The Evolving Concept of 'Court Security'. Justice System Journal. 28: 40-45.

Dominion Post (2008) Keeping Safe in Our Courts, 30 January.

Etter, G. and Swymeler, W. (2010) Courthouse Shootings 1907-2007. Homicide Studies, 14: 90-100. 
Government of Western Australia (2008) Review of Prisoner Transport Services, Perth: Department of Correctional Services and Government of Western Australia.

Harding, R. (2000) Privatising Justice Support and Prison Administration Functions: A WA Exemplar of Effective Regulation and Accountability. Western Australian Law Review. 29: 233-250.

Johnston, L. (2003) From 'pluralisation' to the 'extended police family', International Journal of the Sociology of Law, 31, 185-204.

Pennells, S. (2004) Sorry they got away, says AIMS. West Australian. July 23, p 4.

Prenzler, T. (2000) The Privatisation of Policing, in R. Sarre and J. Tomaino (eds.), Considering Crime and Justice: Realities and Responses. Adelaide: Crawford House Publishing.

Prenzler, T. and Sarre, R. (2008a) Protective security in Australia: Scandal, Media Images and Reform. Journal of Policing, Intelligence and Counter Terrorism. 3: 23-37.

Prenzler, T. and Sarre, R. (2008b) Developing a risk profile and model regulatory system for the security industry. Security Journal. 21: 264-277.

Prenzler, T. and Sarre, R. (2011) An Overview of Security Industry OH\&S in Australia. Sydney: Report to the Australian Security Industry Association Limited. In press.

Raftery, W. (2007) Editor's Introduction, Mini-Symposium on Court Security. Justice System Journal. 28: 16-19.

Sarre, R. (2005) Researching Private Policing: challenges and agendas for researchers. Security Journal. 18: 57-70.

Sarre, R. (forthcoming 2010) Private Policing: some legal musings. Journal of the Australasian Law Teachers Association. In press.

Sarre, R. and Prenzler, T. (2009) The Law of Private Security in Australia. 2nd edition, Sydney: Thomson LBC.

Sarre, R. and Prenzler, T. (2010) Security in Courts: Issues and Options. Paper presented at the 3rd Justice Environments Conference, University of Western Sydney, Sydney, 21 May.

Shichor, D. and Gilbert, M. J. (eds) (2001) Privatization in Criminal Justice: Past, Present and Future, Cincinnati, Ohio: Anderson.

Southland Times (2008) Court Security Incidents, reported on line, 9 August.

Stenning, P. (2000) Powers and Accountability of Private Police. European Journal on Criminal Policy and Research. 8: 325-352.

Stenning, P. (2009) Governance and Accountability in a Plural Policing Environment - The Story So Far. Policing A Journal of Policy and Practice. 3: 22-33.

Sunday Herald Sun (2008) Knife Threat in Children's Court, by James Campbell, 17 August.

Taranaki Daily News (2010) Accused Cuts Arm in Court, by Lyn Humphreys, 19 February.

van Dijk, J. (2008) The World of Crime. Los Angeles: SAGE.

van Steden, R. and Sarre, R. (2007) The growth of private security: Trends in the European Union. Security Journal. 20: 222-235.

Office of the Inspector of Custodial Services (2006) Report of an Announced Inspection of Metropolitan Court Security and Custodial Services, Report No. 31, Perth: Western Australian Office of the Inspector of Custodial Services.

Office of the Inspector of Custodial Services (2007a) Report of an Announced Inspection of Regional Court Security and Custodial Services (CSCS), Report No. 40, Perth: Western Australian Office of the Inspector of Custodial Services.

Office of the Inspector of Custodial Services (2007b) Thematic Review of Custodial Transport Services in Western Australia, Report No. 43, Perth: Western Australian Office of the Inspector of Custodial Services.

Office of the Inspector of Custodial Services (2010) Thematic Review of Court Security and Custodial Services in 
Western Australia, Report No. 65, Perth: Western Australian Office of the Inspector of Custodial Services.

Figure 1: Segregation and flow in Court Precincts (Boswell, 2011)

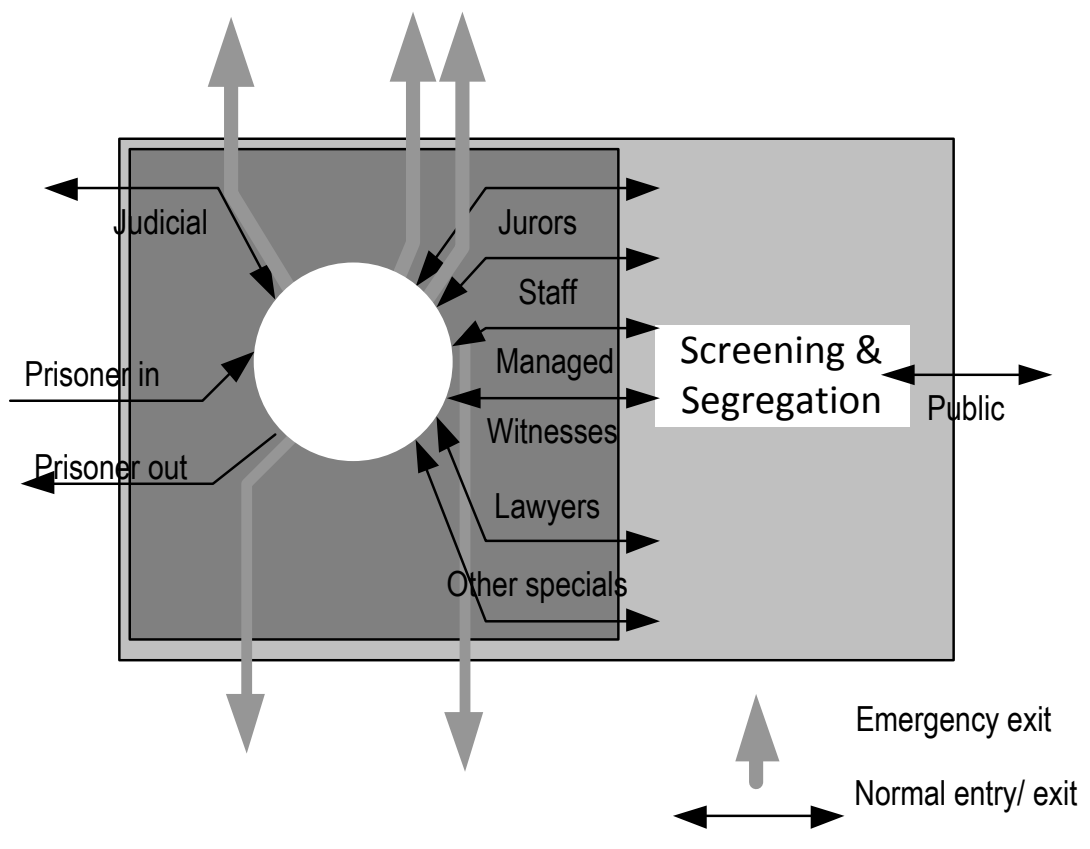

